\title{
Abnormal periostracum secretion during the mineralization process of the pearl in the blacklip pearl oyster Pinctada margaritifera
}

\author{
Michel Comps ${ }^{(\mathrm{a} *)}$, Christian Herbaut ${ }^{(\mathrm{b})}$, Angélique Fougerouse ${ }^{(\mathrm{c})}$ \\ (a) Ifremer, chemin de Maguelonne, 34250 Palavas-Les-Flots, France \\ (b) CUPF, BP 6570, Faa, Aeroport Tahiti, French Polynesia \\ (c) SRM, BP 20-98713, Papeete Tahiti, French Polynesia
}

Received September 15, 1999; accepted December 3, 1999

\begin{abstract}
Whitish parasite-like bodies (PLBs), 0.5-2 $\mu \mathrm{m}$ in size, were detected within the pearl bag of some grafted pearl oysters, Pinctada margaritifera, from Takapoto island (French Polynesia). Histological and ultrastructural investigations have revealed that these bodies consisted of lamellar organic material locally secreted by some epithelial cells of the pearl bag. The fine structure and the formation of these bodies are described. The causes of this abnormal secretion of organic mater, which actually corresponds to periostracum, are not presently known. No parasite nor infectious micro-organism was found associated with the PLBs. C) 2000 Ifremer/Cnrs/Inra/Ird/Cemagref/ Éditions scientifiques et médicales Elsevier SAS
\end{abstract}

Pinctada margaritifera / pearl bag / periostracum

\section{INTRODUCTION}

The development of the culture of the blacklip pearl oyster, Pinctada margaritifera, in French Polynesia was disturbed during $1984-1985$ by a shell disease with associated mortalities [2, 9]. Since this time, because of the economic importance of this species, a zoosanitary survey has been performed on natural and cultivated stocks. Previously only two parasites have been reported in $P$. margaritifera. A gregarine was found in animals from the Tuamotu archipelago [4]; more recently, the presence of a procaryote infecting the digestive epithelium was reported by Comps et al. [5].

In the lagoon of Takapoto (Tuamotu archipelago), the pearl producers have reported over several years the presence, inside the pearl bag, of unusual structures. They suspected these structures to be parasites, possibly associated with abnormalities of mineralization of the pearl. Surprisingly, such parasite-like bodies (PLBs) were found only in the pearl oysters from
Takapoto island with a prevalence of about $0.5 \%$. Despite this low prevalence, the occurrence of such an abnormality has aroused the interest of the pearl producer, because it concerns the mechanisms involved in the formation of the pearl and could be associated with imperfections on the pearl surface.

A light and electron microscope study was carried out to investigate the structure and possible origin of the PLBs. Additional information was gained about secretion of periostracum from pearl sack epithelium.

\section{MATERIALS AND METHODS}

Morphological characterization of the PLBs was made from Pinctada margaritifera growing in the Takapoto lagoon. Pearl bags that contained PLBs, identified by the presence of light spots in the tissues, were sectioned and prepared for microscopic investigation. For light microscopy, samples of PLBs were preserved in Davidson fixative [21] and sections were stained according to the Mann-Dominici method. For

\footnotetext{
* Corresponding author: michel.comps@ifremer.fr
} 


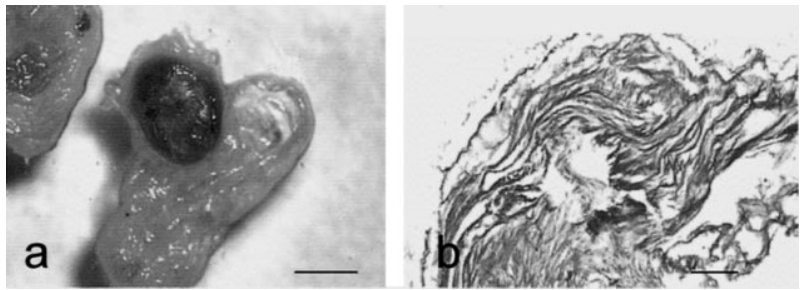

Figure 1. Parasite-like body (PLB) extracted from pearl sack tissue. (a) Parasite like-body (PLB) seen under binocular, bar = $1 \mathrm{~mm}$. (b) Section through a PLB, Mann-Dominici staining, bar $=100 \mu \mathrm{m}$.

transmission electron microscopy (TEM), tissues were fixed overnight at $4{ }^{\circ} \mathrm{C}$ in $2.5 \%$ glutaraldehyde buffered with $0.4 \mathrm{M}$ sodium cacodylate ( $\mathrm{pH} 7.2$ ), postfixed at room temperature in $1 \% \mathrm{OsO}_{4}$ and embedded in Epon resin. Sections were contrasted with saturated uranyl acetate in $50 \%$ ethanol, followed by lead citrate [18]. Semi-thin sections stained with buffered toluidine blue (1\% toluidine blue in $1 \%$ sodium tetraborate) were also used for light microscope examination.

For scanning electron microscopy (SEM) examination, pearls were water cleaned and dried before being gold coated.

\section{RESULTS}

\subsection{Gross signs and histology}

During extraction of the pearl, PLBs were visible because of the thinness and transparency of the pearl sack and appeared as whitish bodies, about 0.5$2.0 \mathrm{~mm}$ in size. Under binocular they exhibited a woolly appearance and histological examination did not show an inner organized stucture (figure $1 a, b$ ).

Longitudinal sections showed that PLBs were contained inside a cavity formed by a circular fold of the inner epithelium of the pearl sack (figure $2 a, b, c$ ). On semi-thin sections stained with buffered toluidine blue, PLBs appeared to be formed as three distinct parts. The first part in contact with the pearl appeared as a layer of amorphous basphilic material, 10-20 um thick, formed of layers of various basophilia. From this material an arborescent structure extended, exhibiting a fractal-like organization which occupied the major part of the PLB (figure $2 d, e, f$ ). The third part, in contact with the pearl sack epithelium, consisted of large areas of homogeneous and purple stained material which was also found in association with other components of the PLB (figure $2 a$ ).

\subsection{Ultrastructure}

\subsubsection{Epithelium of the pearl sack}

At PLB level, some cells bordering the inner side of the pearl sack displayed various stages of a process of secretion. Electron dense granules, of about $2 \mathrm{~nm}$ in size, were found inside the vesicles of Golgi complexes. Similar granules were also seen within small round vesicles, 50-100 $\mathrm{nm}$ in diameter, which seemed to be formed by budding from the Golgi saccules (figure $3 b$ ). These vesicles could aggregate and form larger vesicles containing dense granules $3-4 \mathrm{~nm}$ in size. The last stage consisted of electron dense granules containing vesicles which migrated toward the apical region of the cell; when the vesicles come into contact with the plasmic membrane, the granules are released into the extracellular space between the microvilli (figures $3 a$ and 4 ) and aggregated between the epithelium and the PLB (figures 4 and 6 ).

\subsubsection{Parasite-like bodies, PLB structure}

The basic element of the lamellar structure of the PLBs consists of a layer of amorphous and moderately electron dense material, on average $45 \mathrm{~nm}$ thick ( $f i g$ ure 5). The outer side of this layer was coated by a 2-nm-thick electron dense pellicle which was in contact with the dense granules described above (figure 7). The opposite side of the dense layer was in contact with slack tissue consisting of fibres and vesicles. This tissue was enclosed within the multiple folds of the dense layer.

\subsubsection{Flaws in the pearl}

The pearls produced in PLBs containing pearl bags exhibited various surface flaws which consisted of small depressions (figure 8a). SEM examination showed a disturbed microstructure of the aragonite layer on the surface of the depression (figure $8 b$ ). In the depression, when visible, aragonite crystals appeared irregularly arranged while, around the depression, the successive nacreous laminae displayed a regular pattern (figure $8 b, c, d$ ).

\section{DISCUSSION}

In the bivalves the aragonite crystals of the nacreous layer of the shell are underlayed by an organic matrix elaborated by epithelial cells of different regions of the mantle during the biomineralization cycle [22, 23]. Similar organic structure is also observed in the nacreous layer formed on the surface of the pearl in Pinctada margaritifera [3]. The results of the present investigation show clearly that PLBs correspond with a focal accumulation of organic material secreted by a few cells of the pearl sack epithelium. Its lamellar structure, resulting from folding of an organic layer, resembles the folded or branch-like structure that Kawakami and Yasuzumi [10] reported in the periostracum forming in the pearl oyster Pinctada martensii Dunker. According to Saleuddin and Petit [20] the 'free periostracum' could form complex loops in the extrapallial space during periostracum formation. Moreover, the thickest parts of the PLBs appear stratified into layers as is the mature periostracum in unionid mussels [20]. Pictures obtained under electron 


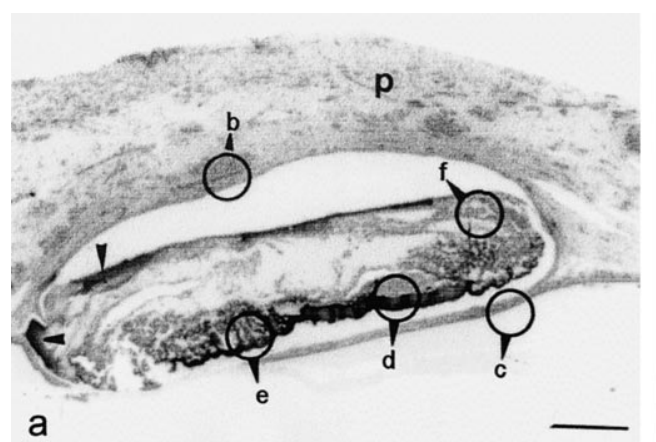

a
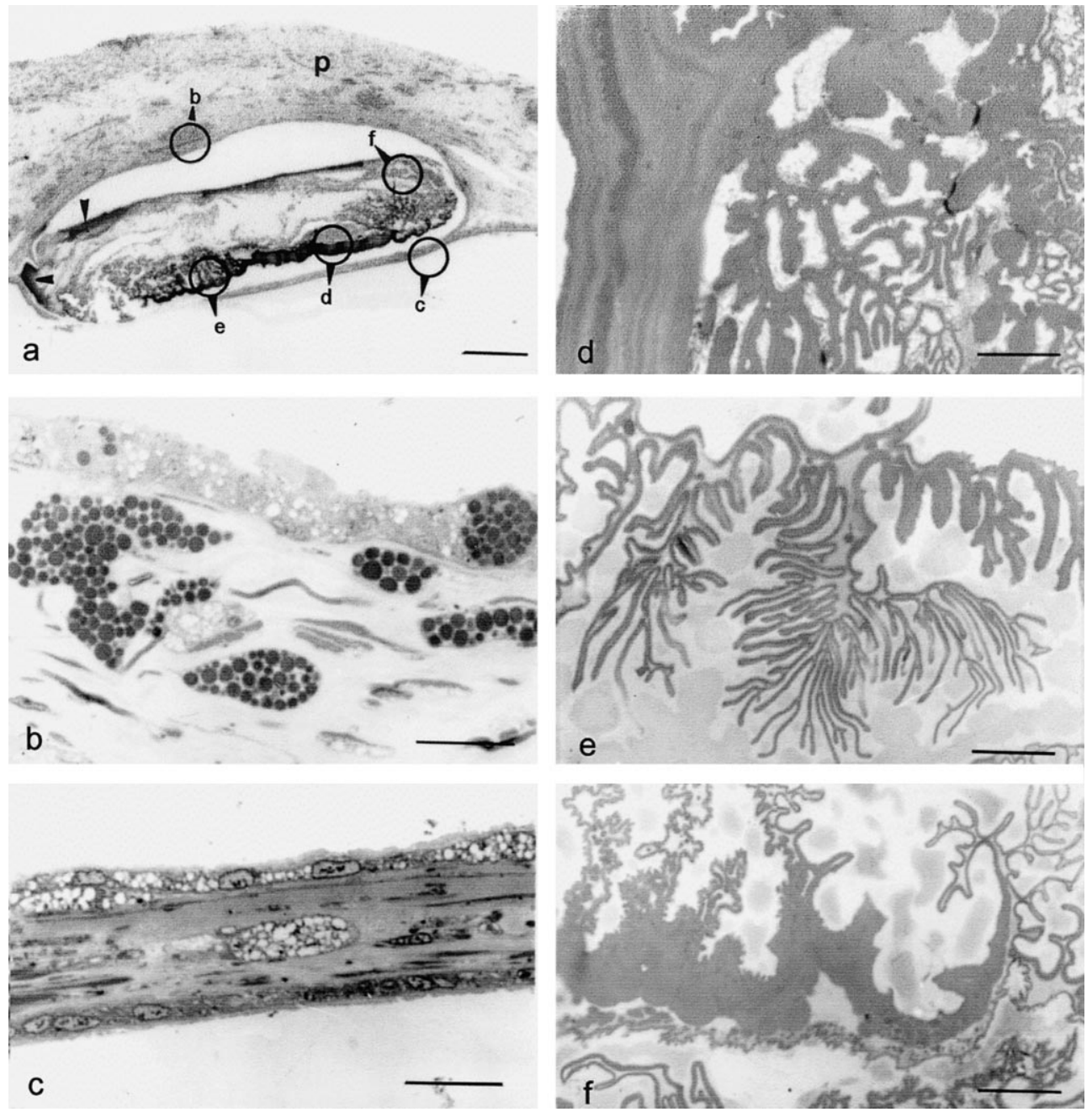

Figure 2. (a) Section through the pearl bag showing the localization of the parasite-like body (PLB) which appears occluded within a cavity formed in the pearl bag tissue by folding of the inner epithelium. Areas of homogeneous material are present between the epithelium and the PLB (heads of arrows). (b) Epithelium of part b of (a). (c) Enlargment of part c of (a): the epithelia are thinner than in part 2 and contain elongated nuclei; note the presence of numerous vacuoles in the inner epithelium. (d, e, f) Higher magnification of parts $d, e, f$ of (a), respectively, showing various aspects of the folded structure which characterizes the PLBs. Semi-thin sections, toluidine blue, bar $=10 \mu \mathrm{m}$.

microscopy show that the successive steps of the secretion of electron dense grains by the cells of the pearl sack epithelium follow the process described by Saleuddin [19]. However, figures of lysosomes fusing with secretory inclusions as reported by this author were not recognized in the pearl oyster. Instead, in the secretory cells of the pearl sack dense grains are first seen within Golgi apparatus from which small vesicles develop, which fuse together and form larger paraspherical vesicles. Granulous material contained within the vesicles is released through the secretory cell between the microvilli. Similar mechanisms of secretion were reported in the clam Mercenaria mercenaria [12] and the mussel Mytilus edulis [1].
The PLBs were first considered by grafters as a parasite, suspected to induce flaws in the nacreous layer of the pearl. The present study shows that the PLBs did not exhibit the morphology of a living organism. Instead, their structure suggests that they may be related to mineralization disturbances associated with abnormal production of laminated organic structure in nacreous layers of the shell and the pearl. Such disorders were reported in the pearl oyster $P$. margaritifera $[7,8,11]$, but their causes remain unknown at present [6]. However similar symptoms, particularly 'anomalous conchiolin deposition' (ACD) observed in other molluscs, have been associated with bacteria. Vibrio harveyi was found in the pearl oyster 

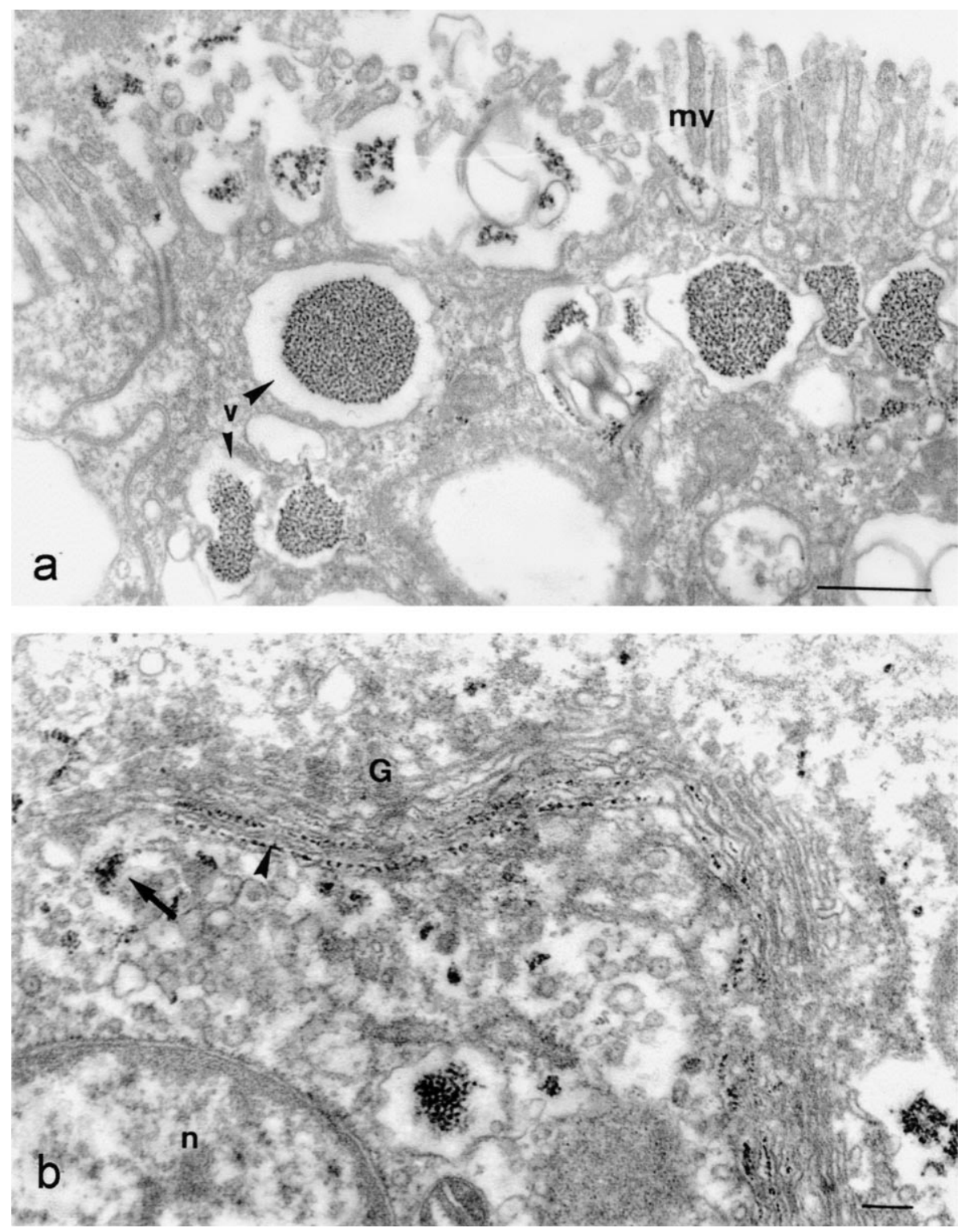

Figure 3. Fine section of pearl sack epithelium at the parasite-like body (PLB) level. (a) Apical region of secretory cell: microvilli (mv), electron dense granules containing vacuoles (v), electron dense granules discharged between the microvilli (g). (b) Golgi complex (g) containing secretory granules (head of arrow); small numbers of granules appear free in the cytoplasm (arrows), probably released from the Golgi cisternae. Transmission electron microscopy $(\mathrm{TEM})$, bar $=100 \mathrm{~nm}$.

P. maxima [16] and Vibrio sp. (named VP1) was isolated as responsible for ACD occurring during the brown ring disease in the Manila clam Ruditapes philippinarum [14]. In these different cases, the bacteria could induce a defence mechanism which becomes apparent by the formation of lamellar deposits of conchiolin $[13,15,17]$. At present, without conceding the possibility of a parasitary origin, we cannot consider that the formation of the PLBs arises from a similar mechanism, since no parasite nor infectious lesion was recognized in either the PLBs or the tissue of the pearl sack.

The PLB development appears as a local disturbance of the mineralizing system, since some epithelial cells of the pearl sack continue locally to secrete organic material that does not participate in the biomineralization process. A similar abnormality involving mineralization disturbances during the initial phase of the pearl bag development was reported by Cuif and Dauphin [6]. According to these authors, the produc- 

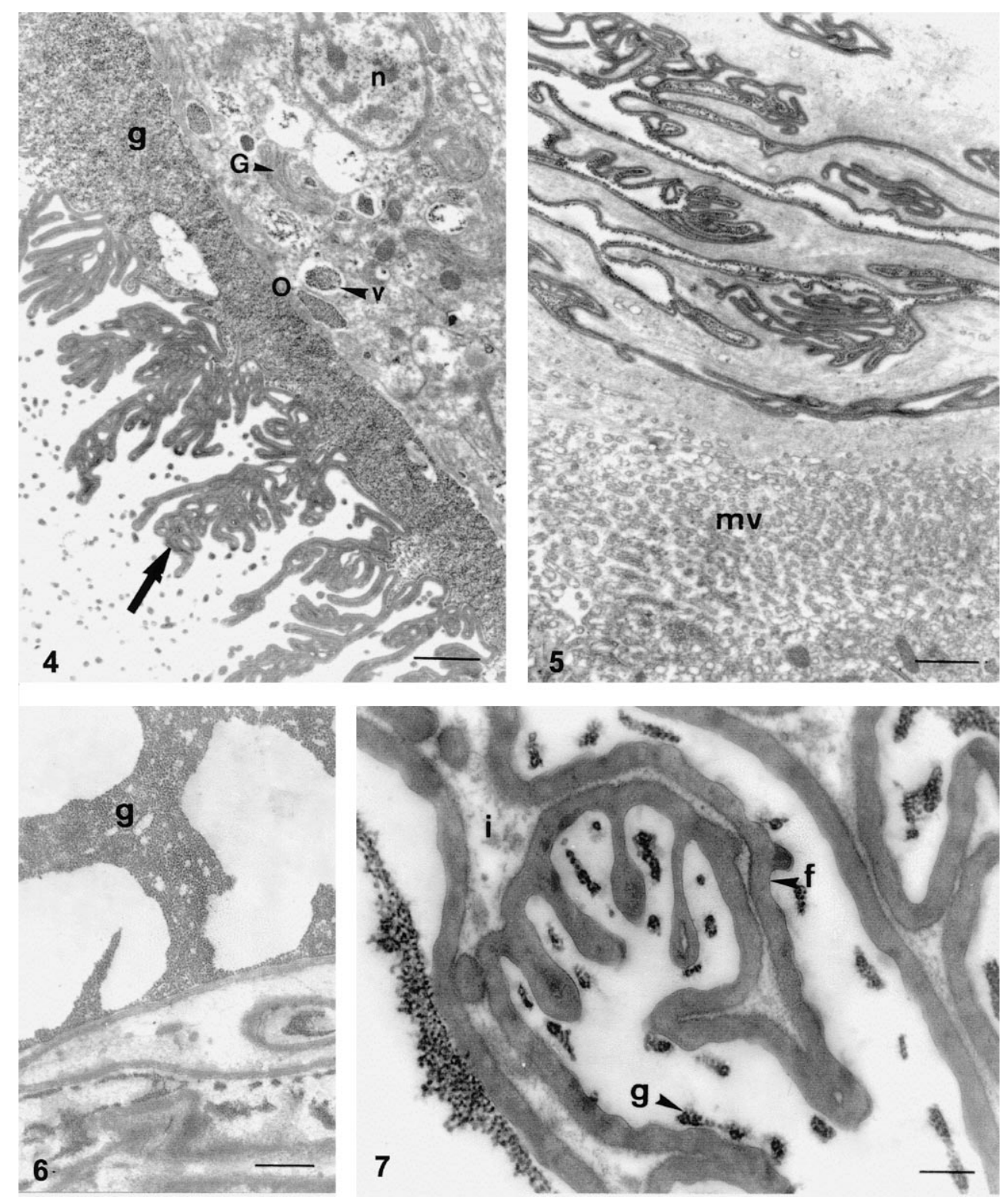

Figure 4. Electron micrograph showing the relationships between the secretory cells and the parasite-like body (PLB): nucleus (n); granules containing vesicles (v); Golgi complex $(\mathrm{G})$; released electron dense granules (g); folded layer of conchiolin forming the PLB (arrow). TEM, bar $=1 \mu \mathrm{m}$.

Figure 5 In some areas, the lamellar structures of the parasite-like body (PLB) are directly in contact with the microvilli (mv) of epithelial cells. TEM bar $=1 \mu \mathrm{m}$.

Figure 6. Section through the parasite-like body (PLB) showing electron dense granules (g) aggregated on the outer side of the conchiolin layer; fibrous material occupies the inner part of the folds. TEM, bar $=500 \mathrm{~nm}$.

Figure 7. Detail of the form of the conchiolin layer. Fine pellicle (f) is apparent on the outer surface of the conchiolin layer; note in the inner part the presence of finely granular and fibrous material (i); electron dense granules (g). TEM, bar $=200 \mathrm{~nm}$.

tion of nacreous crystals could be stopped by stress caused by grafting, and a purely organic layer should be deposited on the nucleus. In the reported study, the secreted organic matter does not deposit on the pearl, but instead aggregates to form the PLBs which should be enclosed within a cavity closed by the extension of 

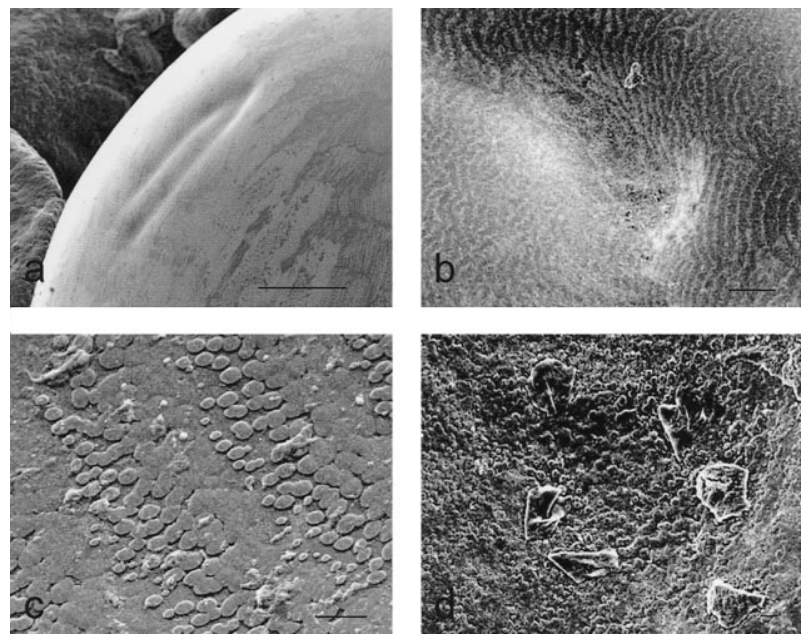

Figure 8. Mineralization disturbances in pearl nacreous layer associated with the presence of the parasite-like bodies (PLBs) in the pearl sack epithelium. (a) Spot dip on the surface of the pearl. Scanning electron microscopy (SEM), bar $=1 \mathrm{~mm}$. (b) At the level of the spot dip, the successive nacreous laminae appear heavily disturbed. SEM, bar $=100 \mu \mathrm{m}$. (c) Detail of the normal structure of nacreous laminae. SEM, bar $=10 \mu \mathrm{m}$. (d) Detail of the bottom of the spot dip displaying incomplete mineralization. SEM, bar $=10 \mu \mathrm{m}$.

\section{REFERENCES}

[1] Bubel A., An electron-microscope study of periostracum formation in some marine bivalves, II. The cells lining the periostracal groove, Mar. Biol. 20 (1973) 222-234.

[2] Cabral P., Some aspects of the abnormal mortalities of the pearl oysters, Pinctada margaritifera L. in the Tuamotu archipelago (French Polynesia), in: Advances in Tropical Aquaculture, Aquacop Ifremer, Actes de colloque 9, 1990, pp. 217-226.

[3] Caseiro J., La nacre noire de Polynésie, Biominéralisation, paramètres et processus de croissance, effets chromatiques dans la coquille et la perle de Pinctada margaritifera, Thèse dr. Univ. Claude Bernard-Lyon I, 1993.

[4] Chagot D., Fougerouse A., Weppe M., Marquès A., Bouix B., Présence d'une grégarine (Protozoa, Sporozoa) parasite de l'huître perlière à lèvres noires Pinctada margaritifera (L., 1758) (Mollusca, Bivalvia) en Polynésie Française, C. R. Acad. Sci. Paris (sér. III) 316 (1993) 239-244.

[5] Comps M., Fougerouse A., Buestel D., A procaryote infecting the black-lipped pearl oyster Pinctada margaritifera, J. Invertebr. Pathol. 72 (1998) 87-89.

[6] Cuif J.P., Dauphin Y., Occurrence of mineralization disturbances in nacreous layers of cultivated pearls produced by Pinctada margaritifera var. cumingi from French Polynesia, Comparison with reported shell alterations, Aquat. Living Resour. 9 (1996) 187-193. the pearl sack epithelium. In these circumstances, flaws observed on the surface of the pearl might be considered as having arisen from mineralization disturbances associated with the PLB formation.

Although numerous studies were carried out on the crystallography of the pearl from $P$. margaritifera [3], little is known about the fine structure of the pearl sack epithelium during the mineralization process of the pearl. In this paper, we show that the epithelium which supplies the crystal deposit may also consist of areas of cells involved in periostracum production. This cell type could be present initially in the mantle tissue used as graft, or it could have differentiated during the formation of the pearl sack epithelium owing to specific factors. Bearing in mind the unusual nature of PLBs, we can provisionally hypothesize that the abnormal secretion of organic matter was a response to a mechanical wound or to the accidental introduction of a foreign body during grafting. It is of interest to note that these points could be checked experimentally.

Acknowledgements. This study was supported by a grant SRM-Ifremer-CUPF (Contrat de développement Etat-Territoire $\mathrm{n}^{\circ}$ 32-96 du 02/09/96. We thank J. Arger for critical review.

[7] Dauphin Y., Cuif J.P., Epizootic disease in the 'black lip' pearl oyster Pinctada margaritifera in French Polynesia: ultrastructural alterations of the nacreous layer, in: Suga S., Nakahara H. (Eds.), Mechanism and Phylogeny of Mineralization in Biological Systems, Springer Verlag, Tokyo, 1990, pp. 167-171.

[8] Dauphin Y., Denis A., Altérations microstructurales de la nacre des huîtres perlières (Pinctada margaritifera) atteintes par l'épizootie en Polynésie française, C. R. Acad. Sci. Paris, ser. III 306 (1987) 649-654.

[9] Fougerouse A., Herbaut C.H., Weppe M., Buestel D., Mise en évidence d'une pathologie d'origine infectieuse, Rapport définitif de la Fiche-Programme $\mathrm{n}^{\circ} 1$, Convention part. $\mathrm{n}^{\circ}$ 09/94 EVAAM-IFREMER, 1994, $56 \mathrm{p}$.

[10] Kawakami I.K., Yasuzumi G., Electron microscope studies on the mantle of the pearl oyster Pinctada martensii Dunker, Preliminary report, The fine structure of the periostracum fixed with permanganate, J. Electr. Microscop. 13 (1964) 119-123.

[11] Marin F., Dauphin Y., Malformations de la couche nacrée de l'huître perlière Pinctada margaritifera (L.) de la Polynésie française : rapport entre altérations microstructurales et composition en acides aminés, Ann. Sci. Nat. Zool, Paris, 13 e ser. 13 (1992) 157-168.

[12] Neff J.M., Ultrastructural studies of periostracum formation in the hard shelled clam Mercenaria mercenaria (L.), Tissue Cell 4 (1972) 311-326.

[13] Oubella R., Maes P., Allam B., Paillard C., Auffret M., 
Selective induction of hemocytic response in Ruditapes philippinarum (Bivalvia) by different species of Vibrio (Bacteria), Aquat. Living Resour. 9 (1996) 137-143.

[14] Paillard C., Maes P., Étiologie de la maladie de l'anneau brun chez Tapes philippinarum : Pathogénicité d'un Vibrio sp., C. R. Acad. Sci. Paris 310 (1990) 15-20.

[15] Paillard C., Maes P., The brown ring disease in the Manila clam Ruditapes philippinarum, I. Ultrastructural alterations of the periostracal lamina, II. Microscopic study of the brown ring syndrome, J. Invertebr. Pathol. 65 (1995) 91-110.

[16] Pass D.A., Dybdahl R., Mannion M.M., Investigations into the causes of mortality of the pearl oyster, Pinctada maxima (Jamson), in Western Australia, Aquaculture 65 (1987) 149-169.

[17] Perkins F.O., Shell disease in the gold lip pearl oyster, Pinctada maxima, and the Eastern oyster, Crassostrea virginica, Aquat. Living Resour. 9 (1996) 159-168.

[18] Reynolds W., The use of lead citrate at high $\mathrm{pH}$ as an electron-opaque stain in electron microscopy, J. Cell Biol. 17 (1963) 208-212.

[19] Saleuddin A.S.M., Ultrastructural studies on the formation of the periostracum in Helix aspersa (Mollusca), Calcif. Tissue Res. 22 (1976) 49-65.

[20] Saleuddin A.S.M., Petit H.P., The mode of formation and the structure of the periostracum, in: The Mollusca, Vol. 4, 1983, pp. 199-234.

[21] Shaw B.L., Battle H.I., The gross and microscopic anatomy of the digestive tract of the oyster Crassostrea virginica (Gmelin), Can. J. Zool. 35 (1957) 325-347.

[22] Wada K., Electron-microscopic observations of the shell structures of pearl oyster (Pinctada martensii), II. observations of the aragonite crystals on the surface of nacreous layers, Bull. Natl. Pearl Res. Lab. (Jpn) 2 (1987) 74-85.

[23] Watabe N., Studies on shell formation, XI. Crystalmatrix relationships in the inner layers of mollusks shells, Ultrastr. Res. 12 (1965) 351-370. 